\title{
David and Goliath: chemical perturbation of eukaryotes by bacteria
}

\author{
Louis K. Ho ${ }^{1} \cdot$ Justin R. Nodwell $^{1}$
}

Received: 6 August 2015 / Accepted: 9 September 2015 / Published online: 3 October 2015

(C) The Author(s) 2015. This article is published with open access at Springerlink.com

\begin{abstract}
Environmental microbes produce biologically active small molecules that have been mined extensively as antibiotics and a smaller number of drugs that act on eukaryotic cells. It is known that there are additional bioactives to be discovered from this source. While the discovery of new antibiotics is challenged by the frequent discovery of known compounds, we contend that the eukaryote-active compounds may be less saturated. Indeed, despite there being far fewer eukaryotic-active natural products these molecules interact with a far richer diversity of molecular and cellular targets.
\end{abstract}

Keywords Actinomycetes $\cdot$ Eukaryotes $\cdot$ Target diversity

\section{Introduction}

Actinobacteria are gram-positive bacteria that are ubiquitous in soil and marine sediments. There are an exceptionally diverse number of genera that include Streptomyces, Micromonospora, Amycalotopsis, Salinospora, Saccharopolyspora, Actinomycetes and many others. These organisms have evolved striking developmental and physiological adaptations that allow them to compete and survive in crowded environments. One notable feature is their ability to produce biologically active small molecules, referred to variously as 'natural products', 'secondary metabolites', and 'specialized metabolites' that have been isolated and used as antibiotics and other therapeutics.

Justin R. Nodwell

Justin.nodwell@utoronto.ca

1 Department of Biochemistry, University of Toronto, 1 King's College Circle, Toronto, ON M5S 1A8, Canada
Drug discovery based on mining metabolites from actinobacteria, based on enormous screens of culture supernatants against pathogenic bacteria, was successful from 1950 to 1970 and generated many of the antibacterial drugs we now have at our disposal. However, the repeated re-discovery of known antibacterials from this source led to the abandonment of this approach during the 1990s. The prevailing view by the mid-1990s was that there was no new chemical diversity left to discover from this source. However, the advent of genome sequencing revealed that the reservoir of biosynthetic genes for these compounds, including polyketides, non-ribosomal peptides and other classes, is much larger than had been previously appreciated $[19,90,138]$. We now know that each actinomycete genome encodes 20-50 biosynthetic gene clusters for secondary metabolites [134]. It is not currently possible to assign a product structure or biological activity to most of these biosynthetic pathways. Indeed, many of the secondary metabolites produced by well-characterized model strains such as Streptomyces coelicolor, Streptomyces griseus and Streptomyces avermitilis are still unknown. As a result, there has been renewed emphasis on the discovery and characterization of these cryptic metabolites through the use of new bioinformatic approaches, innovative culture techniques, genetic manipulation, chemical manipulation and new screening regimens $[40,41,69,194,103,109,117,127$, 136, 151, 165, 173].

There are several explanations for why so many secondary metabolites have eluded discovery. One view is that many secondary metabolic genes are expressed at low levels in the laboratory and that their products cannot therefore be easily detected. Another is that there may be a 'screening bias' in the existing discovery regimens. For example, the vast majority of screening has been for antibiotics-it is 
Table 1 The eukaryotic targets of actinomycete metabolites

\begin{tabular}{|c|c|c|}
\hline Drug & Producer & Primary target \\
\hline \multicolumn{3}{|l|}{ Nucleotide synthesis } \\
\hline Actinomycin D & Streptomyces spp. & DNA \\
\hline Bleomycin & Streptomyces verticillus & DNA, RNA \\
\hline Calicheamicin & Micromonospora echinospora & DNA \\
\hline Doxorubicin & Streptomyces peucetius & DNA \\
\hline Mitomycin & Streptomyces spp. & DNA \\
\hline \multicolumn{3}{|l|}{ Sterols } \\
\hline Amphotericin B & Streptomyces nodosus & Ergosterol \\
\hline Candicidin & Streptomyces griseus & Ergosterol \\
\hline Natamycin & Streptomyces natalensis & Ergosterol \\
\hline Nystatin & Streptomyces noursei & Ergosterol \\
\hline \multicolumn{3}{|l|}{ Immunosuppression } \\
\hline Ascomycin & Streptomyces hygroscopicus & FKBP12, Calcineurin \\
\hline FK506 & Streptomyces tsukubaensis & FKBP12, Calcineurin \\
\hline Rapamycin & Streptomyces hygroscopicus & FKBP12, mTOR \\
\hline \multicolumn{3}{|l|}{ Mitochondrial function } \\
\hline Antimycin A & Streptomyces spp. & Cytochrome $\mathrm{C}$ reductase \\
\hline Oligomycin & Streptomyces distatochromogenes & ATP synthase \\
\hline \multicolumn{3}{|l|}{ Protein degradation } \\
\hline Epoxomicin & Streptomyces hygroscopicus & $20 \mathrm{~S}$ proteasome \\
\hline Salinosporamide A & Salinospora spp. & $20 \mathrm{~S}$ proteasome \\
\hline \multicolumn{3}{|l|}{ Neurotransmission } \\
\hline Avermectin & Streptomyces avermectinius & GluCl channel \\
\hline Milbemycin & Streptomyces hygroscopicus & GluCl channel \\
\hline Spinosyn & Saccharopolyspora spinosa & nACh receptor \\
\hline \multicolumn{3}{|l|}{ Membrane } \\
\hline Ionomycin & Streptomyces conglobatus & Lipid bilayer \\
\hline Nigiricin & Streptomyces hygroscopicus & Lipid bilayer \\
\hline Valinomycin & Streptomyces spp. & Lipid bilayer \\
\hline \multicolumn{3}{|l|}{ Vacuolar pH } \\
\hline Bafilomycin & Streptomyces griseus & V-ATPase \\
\hline Concanamycin & Streptomyces neyagawaensis & V-ATPase \\
\hline \multicolumn{3}{|l|}{ Signaling } \\
\hline Lavendustin A & Streptomyces griseolavendus & Tyrosine kinase \\
\hline Sangivamycin & Streptomyces rimosus & Protein kinase $\mathrm{C}$ \\
\hline Staurosporine & Streptomyces staurosporeus & Protein kinase $\mathrm{C}$ \\
\hline \multicolumn{3}{|l|}{ Other } \\
\hline Borrelidin & Streptomyces parvulus & Threonyl-tRNA synthetase \\
\hline Cycloheximide & Streptomyces griseus & $60 \mathrm{~S}$ ribosome \\
\hline Geldanamycin & Streptomyces hygroscopicus & Hsp90 \\
\hline Leptomycin B & Streptomyces spp. & CRM1 (exportin) \\
\hline Rebeccamycin & Streptomyces spp. & Topoisomerase I \\
\hline Trichostatin A & Streptomyces spp. & HDAC (class I and II) \\
\hline Tunicamycin & Streptomyces spp. & UDP-HexNAc \\
\hline
\end{tabular}

possible that some of the uncharacterized chemical matter act on other targets.

The primary focus in this field since its inception has been on the discovery of new antibiotics. This charge has been renewed most recently due to a pressing need for new approaches to treating resistant pathogens $[15,16]$. Nevertheless, we wonder whether some of the diversity of natural products is being overlooked. It is known for example, 
that there are many secondary metabolites that interact with eukaryotic cells (Table 1). These include known secondary metabolites commonly used as clinical antifungal, anticancer, immunosuppressive, antiangiogenic, and antiprotozoal drugs [20]. As we will describe in this review, the target diversity of these eukaryote-directed compounds exceeds that of the antibacterials. Indeed, another explanation for the failure to discover some of this diversity could be that the screening bias towards finding antibacterials has caused compounds that are expressed in the lab to go undetected due to the fact that the wrong assay was employed. Our intent, therefore, is to examine a selection of known eukaryote-directed secondary metabolites in the interest of stimulating the discovery of secondary metabolites that act on eukaryotic targets. In addition to providing new probes of intricate biological pathways, such molecules could provide leads for new therapeutics against many diseases.

\section{Targeting DNA synthesis: doxorubicin}

One of the mainstays of cancer chemotherapy involves the use of the anthracycline drugs epirubicin, pirarubicin, aclarubicin and idarubicin, all of which are derived from the foundational drug doxorubicin. These drugs are routinely used against malignancies such as adult acute leukemia, breast carcinoma, non-Hodgkin's lymphoma and ovarian carcinoma [39, 89]. Indeed, the first clinically approved nano-drug (Doxil ${ }^{\circledR}$ ) was a liposomally encapsulated form of doxorubicin used for the treatment of AIDS-induced Kaposi's sarcoma and solid tumours [17].

The first member of this class, daunorubicin, was isolated from Streptomyces peucetius in 1963 and found to be effective against murine tumours [48]. However, clinical trials revealed severe cardiotoxicity so the compound was abandoned [170]. In an effort to find a more therapeutically favourable analogue, Arcamone et al. mutagenized $S$. peucetius and isolated strains that produced an altered, and more clinically favourable form of the drug that was named doxorubicin [4]. Doxorubicin is still toxic however it can be dosed so as to maximize its anticancer activity and minimize damage to normal tissue. Both compounds are planar tetracyclic structures attached to an amino sugar moiety: doxorubicin differs from daunorubicin by a single hydroxyl group (Fig. 1a).

The earliest indication of doxorubicin's mechanism of action came from in vivo assays showing reduced RNA synthesis in HeLa cells [49]. In that same year, Calendi et al. observed distinct changes in the physical properties of DNA when incubated with the drug in vitro [33]. Indeed, crystal structures [63] and NMR spectroscopy [195] of doxorubicin-DNA complexes show that the drug intercalates between the nitrogenous base pairs by planar insertion (Fig. 1b).

Doxorubicin was found to induce double strand breaks in the DNA of leukemic cells where the ends of the broken strands were associated with a protein complex. The protein was subsequently identified as topoisomerase II, the homodimeric enzyme responsible for relieving positive supercoiling by a double-strand cleavage and rejoining mechanism [172]. This and other work led to a model where doxorubicin intercalates DNA causing topoisomerase II to become trapped resulting in a ternary complex and a double-strand break [119]. The exact molecular mechanism of this process is not fully understood, however several mutagenesis studies in yeast implicate the CAP-like DNA-binding domain of topoisomerase II as a direct target $[130,144]$.

This model is widely recognized as doxorubicin's primary mechanism of targeting proliferative cancerous cells in vivo. However there is support for alternative mechanisms in the literature. This includes most notably the generation of reactive oxygen species (ROS) [101] and genespecific damage [35, 93]. It is possible that these alternative mechanisms occur simultaneously and are concentration dependant [66].
Fig. 1 a The chemical structure of daunorubicin and doxorubicin (Prod. S. peucetius). b Crystal structure of DNA-doxorubicin associated complexes. The tetracyclic rings intercalate between base pairs while the aminosugar rests in the minor groove of DNA (PDB:1D12) a<smiles>[R]CC(=O)[C@]1(O)Cc2c(O)c3c(c(O)c2[C@@H](OC2CC(N)C(C)C(O)C2O)C1)C(=O)c1c(OC)cccc1C3=O</smiles> 


\section{Targeting fungal membranes: amphotericin B}

Many antibiotics produced by actinomycetes target fungal cells [20]. The most clinically relevant class in this category are the polyene macrolides, particularly amphotericin $\mathrm{B}$, isolated in 1953 at the Squibb Institute from the fermentation of S. nodosus [52]. Amphotericin B is a mainstay for managing systemic fungal infections. Amphotericin $\mathrm{B}$ is active against many fungal pathogen species in vitro including Candida albicans [10, 145], Aspergillus fumigatus [8, 55], Cryptococcus neoformans [10, 44], Blastomyces dermatitidis [114, 166], Histoplasma capsulatum [114], Rhizopus sp. [55, 56] and Mucroales sp. [156]. Despite amphotericin B's long-standing monotherapeutic use over the last 50 years, few resistant strains have emerged.

This is due to a tradeoff between tolerability and the fitness that is believed to limit resistance from developing [179]. However, a number of amphotericin B-resistant strains of Aspergillus [167], Cryptococcus [123] and Candida [190] have emerged in the clinic in recent years. In addition, amphotericin B treatment is often associated with adverse effects including nephrotoxicity [186] and anemia [116, 121, 193]. Interestingly, amphotericin B-induced anemia has been shown to occur through the inhibition of the transcription factor hypoxia-inducible factor-1 (HIF-1), thereby reducing the expression of erythropoietin (EPO) which controls red blood cell proliferation [121, 193].

Amphotericin B is comprised of an amphipathic macrolactone ring with a mycosamine attachment (Fig. 2a). These molecular features work together to bind fungalspecific sterols such as ergosterol in the membrane, causing ion-leakage [11, 28]. Hydrogen bonds formed between the mycosamine of amphotericin B and the hydroxyl group present in both ergosterol (fungal) and cholesterol (human) are essential for binding to occur [141]. Amphotericin B's selective toxicity towards fungi is due to a more stable interaction between its seven conjugated double bonds with ergosterol [150, 177], presumed to be the result of reduced conformational flexibility [12].

An early model of amphotericin B's mechanism of action was the 'barrel-stave' $[125,176]$. In this model,

a
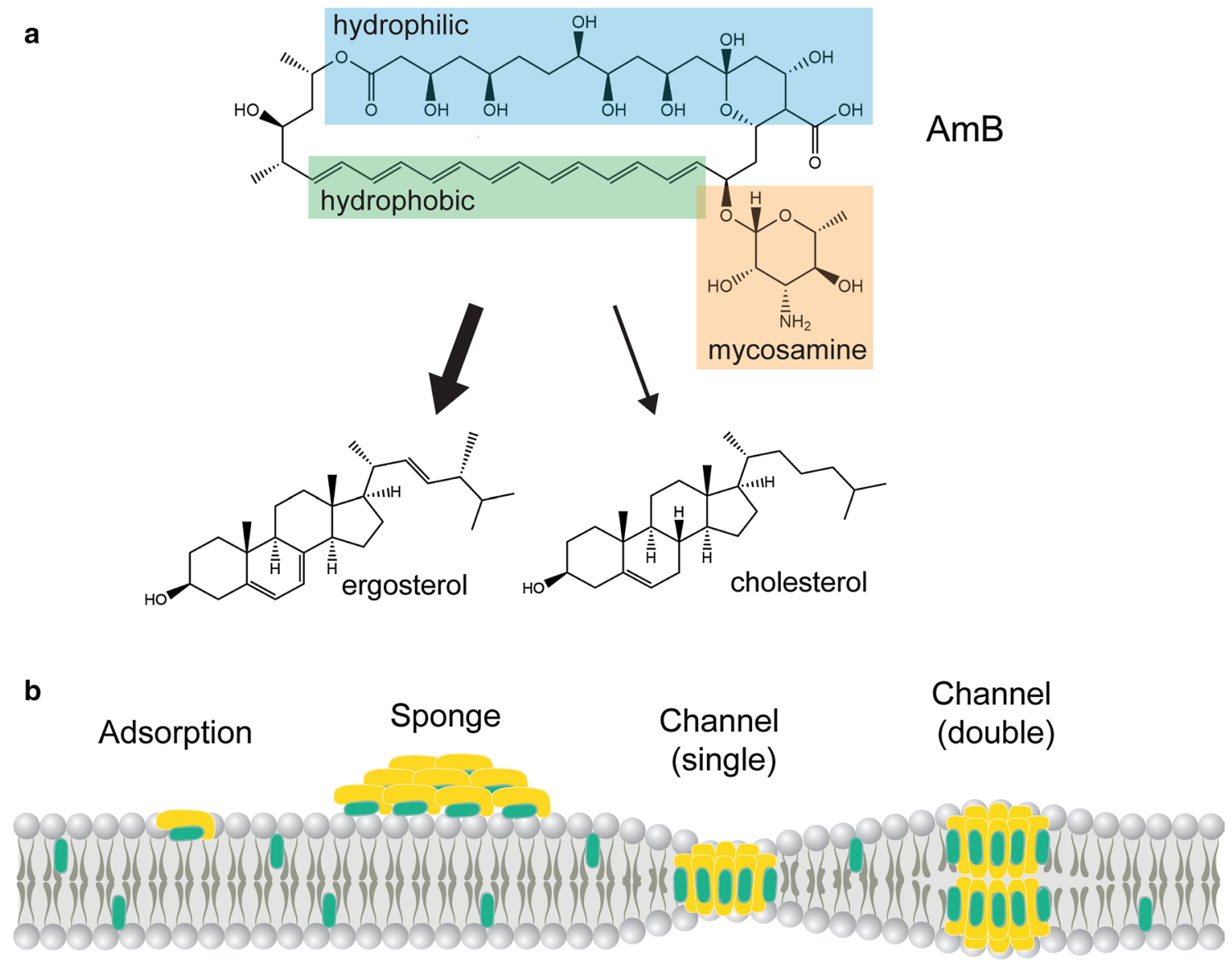

Fig. 2 a The chemical structure of amphotericin B (Prod. S. nodosus). Highlighted are the drug's molecular features that confer its specificity for ergosterol in fungi rather than cholesterol in mamma- lian cells. b Models of amphotericin B-ergosterol interactions with the lipid bilayer in fungi 
eight amphotericin B-sterol complexes are aligned perpendicularly to the lipid bilayer forming a channel with the hydrophobic face on the exterior and the hydrophilic face pointing towards the interior (Fig. $2 \mathrm{~b}$ ). $\mathrm{K}^{+}$ions would then leak out of the cell resulting in membrane depolarization and eventually cell death [5, 108]. Furthermore, amphotericin B forms ion channels more easily in the presence of ergosterol [88]. Recent studies by Gray et al. have challenged the notion that ion leakage by pore formation is the sole biochemical feature in its mechanism of action [70]. In particular, they found that a chemically modified analogue, $\mathrm{C} 35 \mathrm{deOAmB}$, lacking the ability to form pores, retained its antifungal potency. Likewise, the related polyene natamycin possesses antifungal activity despite its inability to form pores in the membrane [184]. An alternative model therefore, is that amphotericin B binds to the membrane monomerically, parallel to the lipid moieties (adsorption) [46, 131] or in aggregates (sponge) [2] to sequester ergosterol thereby causing a global reduction of sterol levels in the membrane. This in turn could limit the sterol's function in maintaining the structural integrity and fluidity of the lipid bilayer as well as enabling the function of membranebound enzymes that influence a wide range of diverse signalling cascades $[115,185]$. While it is likely that monomeric, aggregated and pore-forming states of amphotericin B occur simultaneously, the ratios at which these formations exist at various concentrations remain unknown.

Ongoing debate about its mechanism of action and toxicity suggests that modification of this drug, or the isolation and investigation of new congeners from other actinomycetes could drive the development of better antifungal drugs. More recently, novel derivatization of amphotericin B using diphenylphosphoryl azide (DPPA) led to two analogues: AmBMU and AmBAU, which were shown to be effective in evading resistance to Candida while having greater selectivity for ergosterol and were thus less toxic to human blood cells [45]. Notably, this study also revealed that amphotericin B-resistant strains of Candida are nonpathogenic in mice suggesting that minor changes in ergosterol significantly reduces pathogenicity. In addition, robust methods of synthesizing less toxic analogues of amphotericin B have been developed using the iterative cross-coupling of polyene building blocks which could potentially provide more potential candidates for improving drug efficacy [113].

It is widely agreed that additional antifungal drugs are needed to combat resistant strains and improve therapeutic outcomes associated with opportunistic mycoses including candiasis, cryptococcal meningitis and aspergillosis which often do not respond well to a limited number of current drug regimens $[54,146]$. Indeed, fungal infections that were previously treated successfully with this drug are showing increasing resistance [67].

\section{Targeting cell growth (mTOR): rapamycin}

The macrocylic lactone antibiotic rapamycin has had an enormous impact on medicine and on our understanding of eukaryotic cells. Its story began in 1964 when a Canadian expedition team collected soil samples from Easter Island in the southeastern point of the Polynesian Triangle in the Pacific Ocean. This soil sample was then investigated at Ayerst Laboratories in Montreal where the molecule, rapamycin (from Rapa Nui, the indigenous name for Easter Island), later derived from the isolated strain S. hygroscopicus, showed remarkable antifungal activity against Candida [178]. Persistent efforts led to rapamycin's rise to acclaim where it was found to possess potent immunosuppressive and antiproliferative properties [86, 124], leading in turn to further investigation of its mode of action.

Initially, the structurally related immunosuppressant FK506 was found to target the 12-kDa FK506-binding protein (FKBP12), a peptidylprolyl romatase [81, 164]. The complex then acquires a gain-of-function ability to suppress the activation of T-cells in the immune system through a third target, calcineurin [104]. Similarly, rapamycin also binds to FKBP12 however mounting evidence suggested that FK506 and rapamycin varied in their mechanism of immunosuppression in murine T-cells $[23,50,51]$, suggesting that the tertiary target of the rapamycin-FKBP12 complex was not the same as FK506. A landmark study by Heitman et al. was carried out in the budding yeast Saccharomyces cerevisiae in which genetic screens led to the identification of dominant mutations in TOR1 and TOR2 that were shown to confer rapamycin resistance [83]. This suggested that the encoded TOR (target of rapamycin) proteins-paralogous serine/threonine kinase subunits-were the targets of the FKBP-rapamycin complex that ultimately resulted in immunosuppression and growth reduction. It was subsequently found that rapamycin binds proteins in a mammalian cells that shared extensive sequence similarity to the TOR1, providing not only direct evidence of the rapmaycin-FKBP binding targets but also showing that the mechanistic targets are highly conserved in lower and higher eukaryotes [29, 42, 153, 154]. X-ray crystallography further elucidated the drug's mode of action showing that rapamycin has two binding sites [13, 37] (Fig. 3a). Most eukaryotic organisms possess one TOR protein. The mTOR (mammalian target of rapamycin) is a large $(289 \mathrm{kDa})$ protein that belongs to the phosphoinositide kinase-related kinase (PIKK) family. It associates with other proteins to form two functionally distinct complexes: mTORC1 and mTORC2.

Proteins that act upstream of mTORC1 mediate intracellular responses to a variety of intra- and extracellular cues: growth factors [61], oxygen levels [9], energy [27, 102], mitogens $[38,57]$ and amino acids $[10,25]$. TSC $1 / 2$ 
a

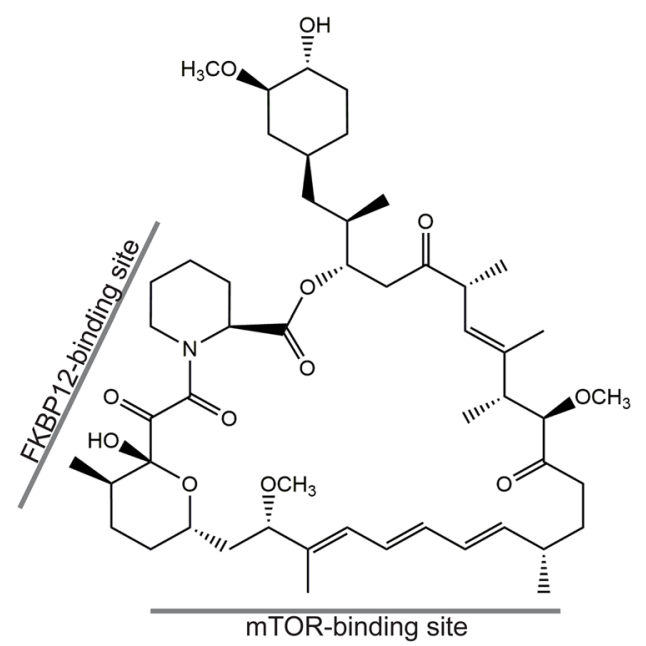

b

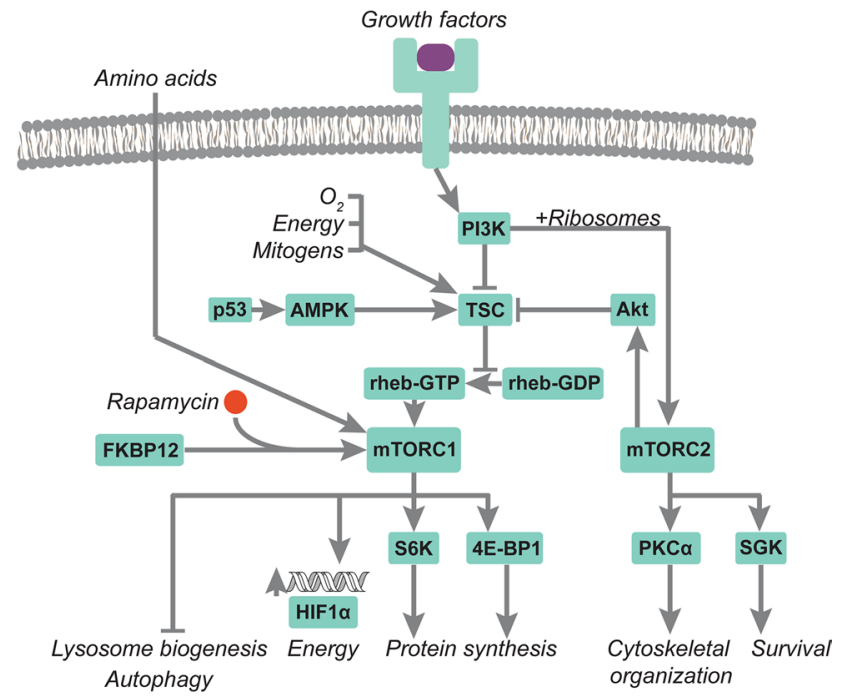

Fig. 3 a The chemical structure and binding regions of rapamycin (Prod. S. hygroscopicus). b In mammals, rapamycin forms a ternary complex with FKBP12 (FK506-binding protein 12) and mTOR

(tuberous sclerosis 1 and 2) are key upstream regulators that inhibit mTORC1 by repressing the formation of the GTP-bound state of Rheb (Ras homolog enriched in brain) [91, 171]. Two downstream effectors phosphorylated by mTORC1 are the eukaryotic translation initiation factor 4E (eIF4E)-bindng protein 1 (4E-BP1) and S6 kinase (S6K) $[21,30,32,80]$. The current model posits that mTORC1 senses environmental cues and works to positively regulate downstream signals of protein synthesis by controlling components within the translation machinery (Fig. 3b).

The mTORC2 signalling network was initially thought to be rapamycin insensitive [95, 157] however, recent studies suggest that mTORC2 does respond to rapamycin in certain cell types after prolonged exposure to the drug [147, 158]. Less is known about the mTORC2 pathway however it has been shown to associate with the ribosome and is required for activation [196]. mTORC2 has been shown to regulate three kinases: Akt [159], serum- and glucocorticoid-induced protein kinase 1 (SKG1) [65] and protein kinase $\mathrm{C}-\alpha(\mathrm{PKC} \alpha)$ [157]. Akt works to phosphorylate downstream processes of survival, apoptosis, growth and proliferation as well as directly feedback into mTORC1 signaling through the inhibition of TSC [72, 92, 94], SKG1 affects ion transport and growth [162] and PKC $\alpha$ affects the remodelling of the actin cytoskeleton [87, 95, 157].

In addition to mediating rapamycin's clinical use for preventing graft rejection after organ transplantation and for treating autoimmune disorders, the components of the mTOR pathway have also been implicated in many other conditions including obesity related type 2 diabetes [105, $112,148,174,175]$ and cancer [73, 182, 189]. Indeed, mutations in negative and positive regulators of mTOR within the mTORC1 (mammalian target of rapamycin complex 1). This pathway is implicated in sensing environmental cues that regulate major cellular outputs

signaling are among the most common tumour suppressors and oncogenes that arise in cancer patients. As a result, a number of rapamycin derivatives (rapalogues) have been approved for the treatment of various cancers [18]. More recently, rapamycin has been explored as a treatment for age related diseases after the drug remarkably was shown to increase the lifespan of yeast [149], nematodes [152], fruit flies [24] and mice [3, 82, 129].

Rapamycin exemplifies the enormous value that eukaryotic targeting compounds can have through the exploration of the drug's mode of action. In addition to the drug and its derivatives being useful therapeutics with a variety of applications, they serve as chemical probes that can be used to elucidate the inner workings of complex biological pathways.

\section{Targeting neurotransmission: avermectin}

The avermectins are a class of macrocyclic lactones that have broad-spectrum activity against nematodes and insects, but that lack antimicrobial activity. In the 1970s researchers at the Kitasato Institute isolated $S$. avermitilis (also referred to as $S$. avermectinius) from a soil sample on a golf course in Shizuoka Prefecture, Japan. The fermentation of this microbe was found to have potent activity against helminth parasitic worm Nematospiroides dubius and remarkably cured the worm-infected mice with little to no toxicity [31]. Soon following, these compounds were identified as a mixture of eight isomers of which avermectins $B_{1 a}$ and $B_{1 b}$ were found to be the most potent derivatives [139] (Fig. 4a). 
a

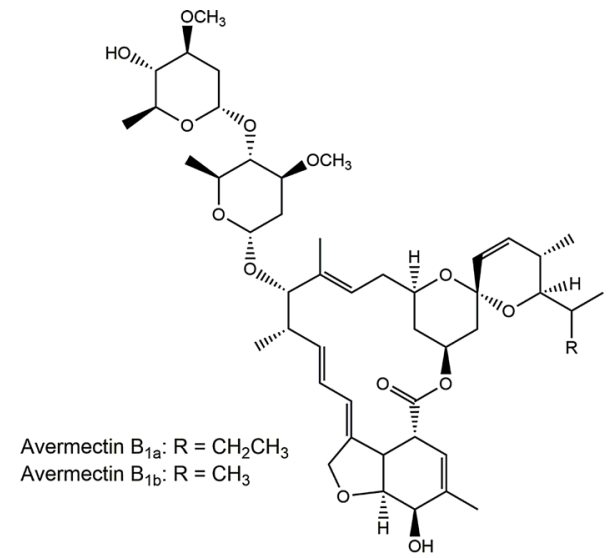

b

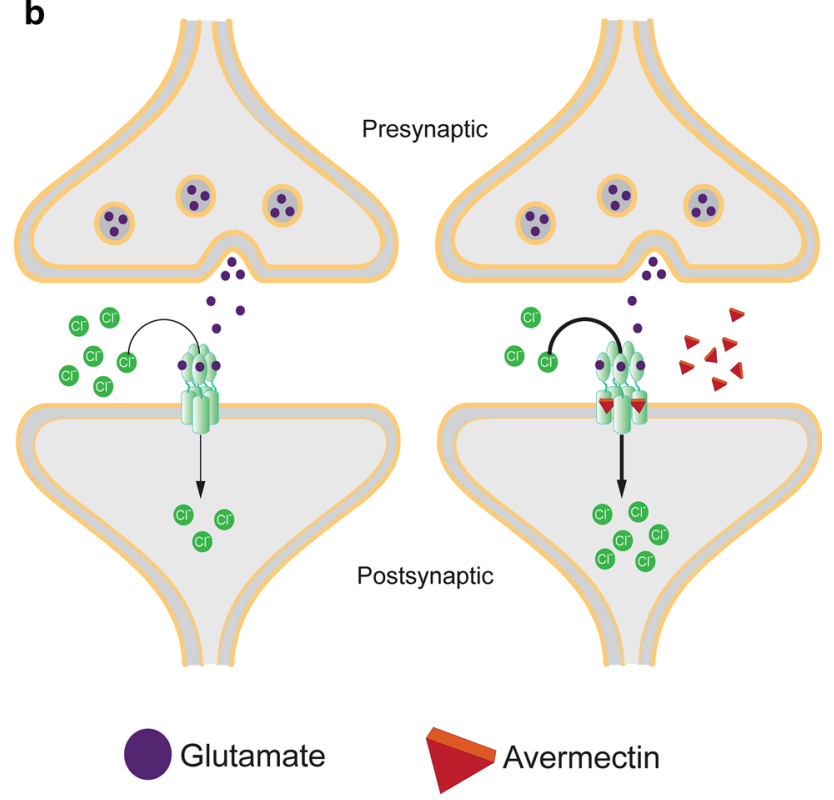

Fig. 4 a The chemical structure of avmermectin B1a and B1b (Produced by $S$. avermitilis). b (Left) At the neuromuscular junction, action potentials are transmitted from the presynaptic to the postsynaptic cell via the neurotransmitter glutamate binding to the $\mathrm{GluCl}$ (glutamate-gated chloride channel) allowing the influx of chloride ions. (Right) Avermectin acts as a $\mathrm{GluCl}$ agonist by increasing ion influx resulting in irreversible hyperpolarization

Avermectin disrupts glutamate-gated chloride channels (GluCls) in nematodes [6,7] and insects [43, 99] that play a critical role in muscle contraction required for locomotion and feeding. The $\mathrm{GluCl}$ channel belongs to a Cys-loop receptor family and is comprised of five subunits. These respond to glutamate to allow the influx of chloride ions to transmit an action potential from the presynaptic to the postsynaptic neuron (Fig. 4b). Avermectin disrupts this process by irreversibly inserting itself between the transmembrane domains thereby causing ions to constitutively leak through the compromised channel [84]. This results in the hyperpolarization of the neuromuscular synapses causing paralysis and subsequent death. It is selective for nematode parasites because mammals do not have GluCls but instead have the evolutionarily related gamma-aminobutyric acid (GABA) receptor channels [188]. While avermectin can bind GABA receptors in the mammalian central nervous system, the pharmacological effectiveness of the drug is owed to its inability to cross the blood-brain barrier [160, 161].

Initially, avermectin was studied for use in veterinary medicine and animal husbandry. The medical formulation of the drug, ivermectin, became useful in agriculture, saving livestock affected by ectoparasitic arthropods and endoparasitic helminth nematodes [34]. But the most significant contribution that this drug has had was its use to treat river blindness, a disease caused by the parasite Oncocerca volvulus that is transmitted by the black fly. Ivermectin is credited for significantly reducing morbidity and transmission of onchocercal infections in the endemic regions of sub-Saharan Africa and Latin America preventing an estimated 600,000 cases of river blindness [26].

\section{Targeting nucleo-cytoplasmic transport: leptomycin B}

Like many compounds that target the eukaryotic cell, leptomycin B and its derivatives were originally identified in screens for antifungal and antitumor antibiotics [77-79, 110]. In 1994, Nishi et al. identified a mutant of the $\mathrm{crml}$ (chromosome region maintenance) gene that conferred leptomycin B resistance in fission yeast [135]. This gene, previously reported by Adachi and Yanagida [1], affected higher order chromosomal structure and resulted in an identical phenotype when mutated compared to leptomycin B-treated cells [135]. This provided strong evidence that the molecular target of leptomycin B was CRM1, a protein that belongs to the importin- $\beta$-like family of nuclear transport machinery that mediates the export of proteins and RNAs out of the nucleus [192].

In order to understand how leptomycin B works, it is important to first recognize the role that the nuclear envelope plays in the cell. That is, the physical separation of the genome and cytoplasm, a central feature of eukaryotic cells. The trafficking of proteins and RNA is a highly coordinated process that takes place across the nuclear envelope which is contiguous with the endoplasmic reticulum and contains anywhere between 200 and 2000 nuclear pore complexes (NPC) that facilitate bi-directional transport between the nuclear and cytoplasmic compartments.

Later, in a screen carried out by Wolff et al. leptomycin $B$ was identified as an inhibitor of the nuclear export of Rev, a protein required for trafficking of HIV-1 mRNA from the nucleus to the cytoplasm [187]. This coincided well with the fact that leptomycin B prevents the cargo-loading of 


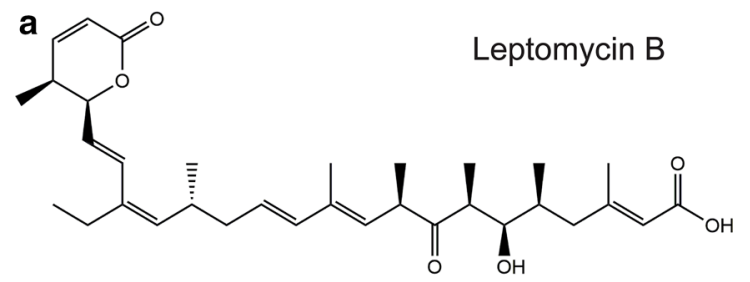

b

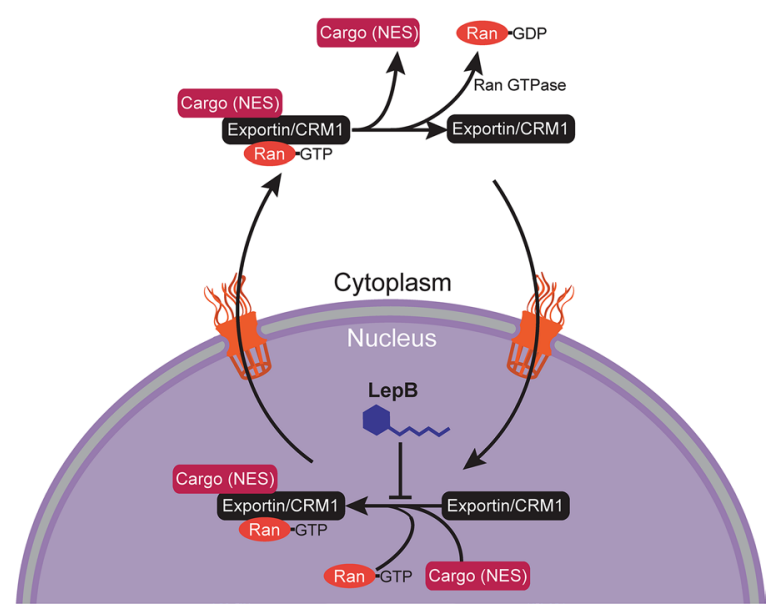

Fig. 5 a The chemical structure of leptomycin B. b Nucleo-cytoplasmic transport of protein cargo with a leucine-rich NES (nuclear export signal) by exportin/CRM1. Leptomycin B inhibits the loading of exportin with the cargo and Ran-GTP by alkylation

proteins that carry leucine-rich nuclear export signals (NES) that are to be transported to the cytoplasm through the nuclear pore [62] (Fig. 5b). It does so by forming a covalent bond with CRM1 where inactivation is thought to occur by a Michael-type addition between the $\alpha, \beta$ - unsaturated lactone terminus of the compound and a key cysteine residue that is essential for leptomycin B sensitivity [111] (Fig. 5a).

The specificity of leptomycin B has been used to validate the CRM1-dependent export of many NES- containing proteins including actin [181], cytokines [140], tyrosine kinases [169], cyclin-CDK [75, 191], MDM2/p53 [64], inhibitors of NF- $\kappa \mathrm{B}$ transcription [155] and MHC class II complexes [36]. Inhibition by this drug results in the accumulation of these key regulatory proteins which eventually leads to cell death.

Efforts have been made to improve the therapeutic efficacy through the synthesis of leptomycin B semi-synthetic derivatives [132]. However, in contrast to many of the well-known actinomycete-derived molecules that target eukaryotic organisms, leptomycin B has gained most of its notoriety as a powerful experimental tool to probe biological complexity.

\section{Targeting the proteasome: epoxomicin}

The 20S proteasome is found in all eukaryotic cells where it serves to degrade proteins during their natural turn-over cycle or proteins that have been misfolded or have sustained other damage. One way that proteins are targeted for proteolysis is via a post-translational modification called 'ubiquitination'. This involves the ligation of a small regulatory protein called ubiquitin to the protein; ubiquitin is then recognized by the proteasome resulting in targeting of the modified adduct for degradation [68].

The $\alpha^{\prime}, \beta^{\prime}$-epoxyketone epoxomicin specifically targets proteasomes, a key protease of intracellular protein degradation. Epoxomicin was discovered in 1992 through a screening programme at Bristol-Myers Squibb in Tokyo, Japan and is produced by the unidentified actinomycete strain Q996-17 where it was initially reported having antitumor activity against B16 melanoma cells in mice [76].

The chemical structure of epoxomicin consists of four linked peptides with an unusual terminal epoxy ketone group (Fig. 6a). This chemical moiety is highly reactive and is therefore considered the 'warhead' or 'pharmacophore' of the drug due to the triangular epoxy ring having highly strained $60^{\circ}$ bond angles which are more stable once decyclized by nucleophilic attack. This inherent instability led to the near abandonment of further development of the drug [100]. However, efforts to understand the epoxomicin's mode of action were continued hoping to gain a better understanding of its antitumor activity.

The peptidic nature of epoxomicin allowed Meng et al. to synthesize the drug with ease which was then biotinylated to chemically attach and immobilize the drug to an affinity column [128]. This, remarkably, led to the epoxomicin-binding proteins being identified as components of the catalytic $\beta$ subunits of the $20 \mathrm{~S}$ proteasome: low-molecular mass polypeptide-7 (LMP7, $\beta 5 \mathrm{i}$ ), subunit $\mathrm{X}$ (PSMB5), which confer chymotrypsin-like activity and multicatalytic endopeptidase complex like 1 (MECL1, $\beta 2 \mathrm{i}$ ), subunit $\mathrm{Z}$ ( $\beta 2$ ), which confer trypsin-like activity to the proteasome. Consistent with the fact that epoxomicin preferentially inhibits the $\beta 5$ subunit of the core proteasomal particle, epoxomicin is highly selective against chymotrypsin-like activity-that is the inhibition of protein cleavage after aromatic and hydrophobic amino acid residues such as tyrosine, tryptophan and phenylalanine [53, 128] (Fig. 6b).

Groll et al. then co-crystallized epoxomicin bound to the yeast 20S proteasome to elucidate the exact molecular mechanism of the epoxomicin-proteasome interaction. The three-dimensional molecular interaction between the drug and the proteasomal catalytic subunit revealed that a covalent linkage with the $\mathrm{N}$-terminal threonine of the proteasome forms a six-membered morpholino ring $[71,183]$. Also showing that epoxomicin fits well into the pocket surrounding the threonine residue within the active site, preferentially binding to the chymotrypsin-like pocket, and at higher concentration than the trypsin-like pocket. 
Fig. 6 a The chemical structure of epoxomicin. b Epoxomicin inhibits the $\beta 5$ subunit of the core $20 \mathrm{~S}$ proteasome thereby inhibiting protein degradation<smiles>CC[C@H](C)[C@H](C(=O)N[C@H](C(=O)N[C@H](C(=O)N[C@@H](CC(C)C)C(=O)C1(C)CO1)[C@@H](C)O)[C@@H](C)O)N(C)C(C)=O</smiles>

Epoxomicin

b

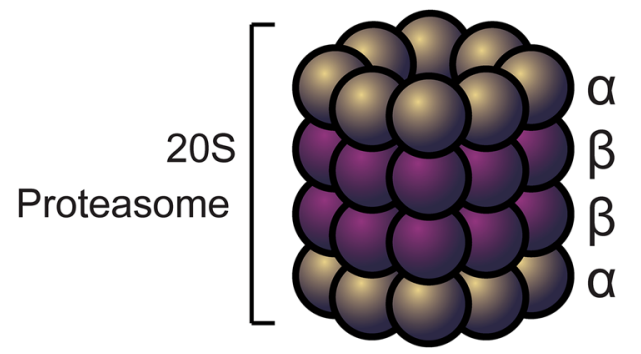

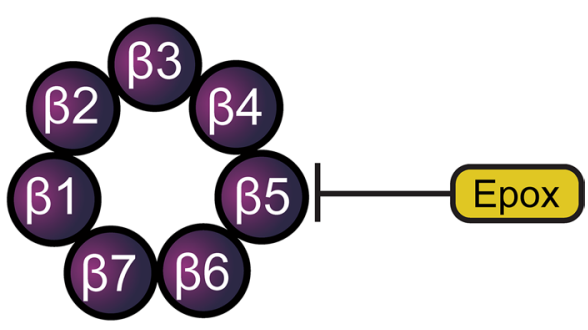

To understand epoxomicin's activity on a cellular level, we will shortly recapitulate the function of the proteasome, the key protease for short-lived proteins regulating a broad variety of cellular processes such as cell cycle progression, gene expression, protein quality control and stress response. Well known proteasomal substrates include cyclins [14, 22], caspases [133, 168], p53 [122], p27 [120] BCL2 [118] and nuclear factor $\kappa B(N F-\kappa B)$ [142]. The inhibition of their proteolysis triggers apoptosis. Thus, chemically induced apoptosis by proteasome inhibitors such as Bortezomib (Velcade ${ }^{\circledR}$ ) are successfully used to combat the progression of certain cancer cells.

Several lines of evidence suggest a heightened dependency on protein quality-control mechanisms mediated by the ubiquitin-proteasome system in cancer cells [74, 85, 120]. Because of this, epoxomicin in combination with proteasome inhibitors are exceptional candidates as antineoplastic therapeutics that can have a very potent cytotoxic effects in cancer cells. In phase I and II clinical trials, inhibition of the $20 \mathrm{~S}$ proteasome is highly cytotoxic to plasma cell cancer multiple myeloma [163] and mantle cell lymphoma [137]. The high expression of proteasomes in proliferative blood cells also suggests that proteasome inhibitors are potentially suited to haematopoietic malignancies [97]. The drug form of epoxomicin (Carfilzomib) is now released as an FDA-approved treatment for relapsed multiple myeloma and is currently undergoing phase III clinical trials [96, 100, 126, 180]. Presumably, higher expression of proteasomes in blood cells compared to peripheral tissues may diminish the drug's access to solid tumors which may limit proteasome inhibitors to blood cancers [47].

Epoxomicin is a rare compound that specifically targets a unique process in eukaryotic organisms, namely chymotrypsin-like activity of the proteasome. Similarly, some other actinomycete-derived proteasome inhibitors: lactacystin [58] and salinosporamide [59], also inhibit the $\beta 5$ catalytic subunit of the $20 \mathrm{~S}$ proteasome which suggests that the proteasome may be a common target for natural products of microbial-origin. There are likely a number of natural products that inhibit the proteasome yet to be discovered.

\section{Eukaryotic targets are more diverse than prokaryotic targets}

\section{Target diversity}

The targets of antibacterials are conspicuously concentrated in four pathways: DNA synthesis, RNA synthesis, protein synthesis and cell wall synthesis [106]. Indeed, there are often multiple targetable proteins in each pathway. For example, tetracycline targets the small $30 \mathrm{~S}$ ribosomal subunit, chloramphenicol targets the large ribosomal subunit and kirromycin targets EF-Tu. Aside from a few minor antibiotics and antibiotic targets (e.g., platensimycin inhibits fatty acid biosynthesis and daptomycin disrupts the cell membrane) these central components of macromolecular synthesis are the targets of virtually all naturally occurring antibiotics that are known at this time.

To date we have identified far fewer eukaryote-active compounds than prokaryote-active compounds among the secondary metabolites produced by actinobacteria. However, the contrast in target diversity could not be greater (Fig. 7). Indeed, Table 1 reveals at least 20 distinct molecular targets in most of the major organelles of the eukaryotic 


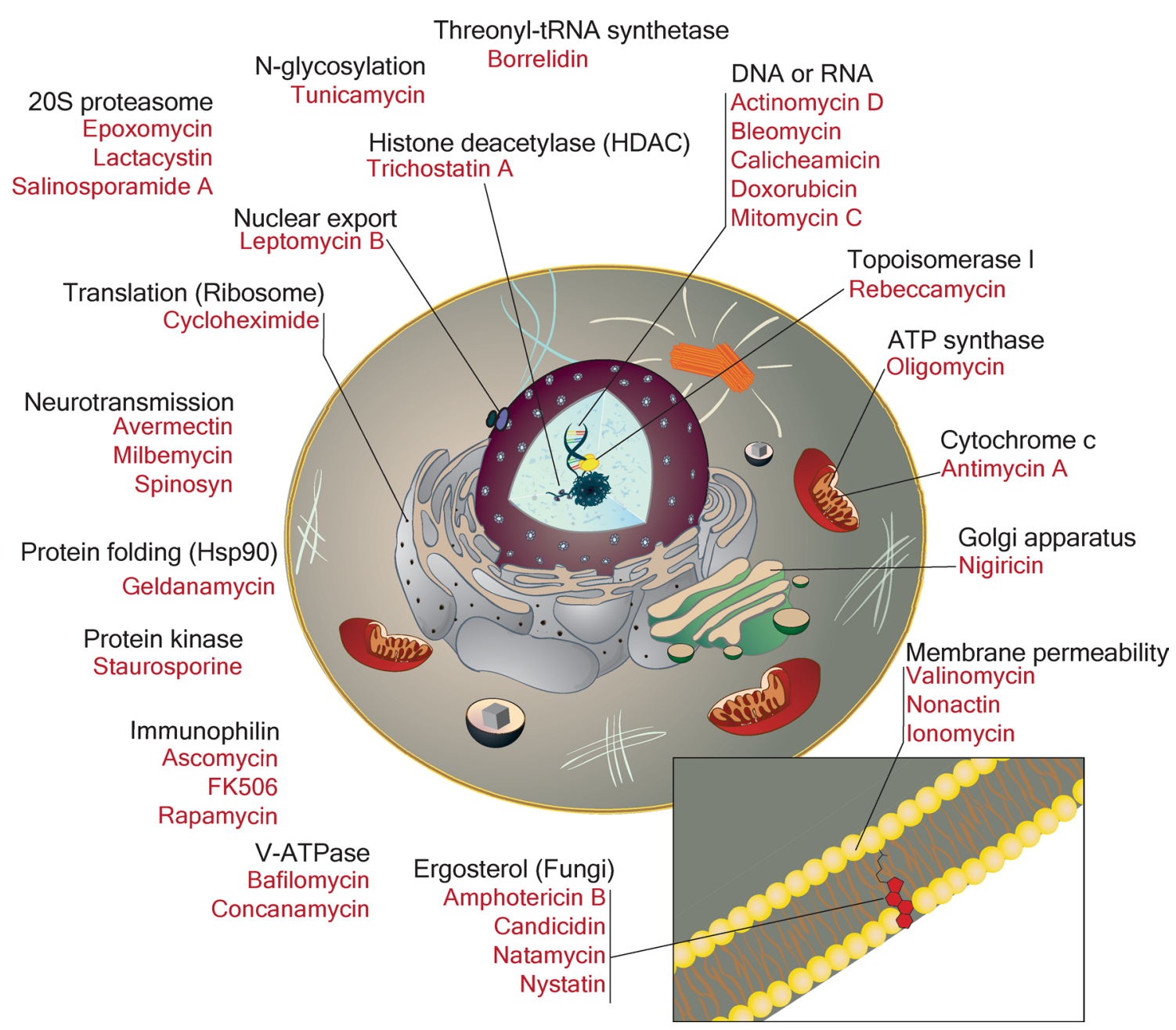

Fig. 7 The highly diverse eukaryotic targets of actinomycete metabolites

cell. In fact, the common antibacterial targets (DNA synthesis, RNA synthesis and cell wall synthesis) are underrepresented relative to the high number of other identified molecular targets in eukaryotic cells.

There are many biosynthetic processes for which there are no natural product inhibitor, and others for which there are only one or two that are known. This, again, is in marked contrast with the antibiotics where dozens of distinct compounds are known that inhibit common targets within bacteria. This suggests that we have yet to reach saturation of possible eukaryotic targets and that additional compounds of interest await discovery. We wonder in particular, whether there are bacterially produced inhibitors of peroxisome biogenesis and function, centrosomes, or even components of key signaling pathways like the Janus kinase/signal transducers (JAK-STAT) pathway, the mitogen-activated protein kinase (MAPK) cascade or regulators of the cell cycle cascade.

How might these questions be addressed? We suggest, as a foundational concept, that any eukaryotic pathway that has been in contact with actinobacteria since its appearance in evolutionary time has a potential biochemical target for a secondary metabolite. The remarkable (though far from exhaustive) description of compound/target interactions that we have provided certainly supports this. Therefore, we propose that more concerted screening campaigns of actinobacterial metabolites against model eukaryotes is a timely and exciting response to this question. These screens should harness more than just live/dead screening. In other words, we should look for interesting developmental and behavioural phenotypes using the well-developed model systems. And in designing screens, we should harness the known molecular biology of the various pathways of interest. In doing so, and by avoiding simple live/dead screens only against microbes, we could avoid the rediscovery of known compounds such as daunorubicin, bafilomycin and cycloheximide and focus our attention on novel chemical scaffolds.

For example, the roundworm Caenorhabditis elegans could be screened for compounds that act via components 
the nervous system and confer motility defects [98]. The fly Drosophila melanogaster could be screened for compounds that interfere with a myriad of developmental pathways, most of which are conserved in humans [143]. Fruiting body formation in the amoeboid organism Dictyostelium discoideum could serve as a reporter for cell adhesion and cell sorting [60]. The simple mustard plant Arabidopsis thaliana offers numerous possibilities for the identification of compounds that interact with the photosynthetic apparatus or other conserved pathways in the plant Kingdom [107]. Indeed, chemical perturbation of the life cycles of many well-characterized eukaryotic organisms also offers the potential for unique insights into both morphogenesis and hidden mechanistic details of eukaryotic cell biology.

We note that the road blocks encountered in antibacterial screening will also be encountered in these searches. Low levels of expression of many secondary metabolic compounds would necessitate strategies for the search for cryptic metabolites, many of which now exist. And the rediscovery of known compounds will also confound some screens. However, this confluence of technologies, the rapidly expanding database of actinobacterial genomes, and the wide-spread interest in chemical inhibitors of eukaryotic life suggests that the time has never been better for a concerted search for new eukaryote-active secondary metabolites.

Acknowledgements We would like to thank Cordula Enenkel, Alexander Palazzo, Leah Cowen, Fiona Smaill, and Anthony Grillo for providing insight and expertise for this review.

Open Access This article is distributed under the terms of the Creative Commons Attribution 4.0 International License (http://creativecommons.org/licenses/by/4.0/), which permits unrestricted use, distribution, and reproduction in any medium, provided you give appropriate credit to the original author(s) and the source, provide a link to the Creative Commons license, and indicate if changes were made.

\section{References}

1. Adachi Y, Yanagida M (1989) Higher order chromosome structure is affected by cold-sensitive mutations in a Schizosaccharomyces pombe gene $\mathrm{crm} 1+$ which encodes a $115-\mathrm{kD}$ protein preferentially localized in the nucleus and its periphery. J Cell Biol 108(4):1195-1207

2. Anderson TM et al (2014) Amphotericin forms an extramembranous and fungicidal sterol sponge. Nat Chem Biol 10(5):400-406

3. Anisimov VN, Zabezhinski MA, Popovich IG et al (2011) Rapamycin increases lifespan and inhibits spontaneous tumorigenesis in inbred female mice. Cell Cycle 10(24):4230-4236

4. Arcamone F, Cassinelli G, Fantini G, Grein A, Orezzi P, Pol C, Spalla C (1969) Adriamycin, 14-hydroxydaunomycin, a new antitumor antibiotic from $S$. peucetius var. caesius. Biotechnol Bioeng 11(6): 1101-1110
5. Arczewska M, Gagos M (2011) Molecular organization of antibiotic amphotericin $\mathrm{B}$ in dipalmitoylphosphatidylcholine monolayers induced by $\mathrm{K}(+)$ and $\mathrm{Na}(+)$ ions: the Langmuir technique study. Biochim Biophys Acta 11:2706-2713

6. Arena JP, Liu KK, Paress PS, Cully DF (1991) Avermectinsensitive chloride currents induced by Caenorhabditis elegans RNA in Xenopus oocytes. Mol Pharmacol 40(3):368-374

7. Arena JP, Liu KK, Paress PS, Schaeffer JM, Cully DF (1992) Expression of a glutamate-activated chloride current in Xenopus oocytes injected with Caenorhabditis elegans RNA: evidence for moduluation by avermectin. Brain Res Mol Brain Res 15(3-4):339-348

8. Arikan S, Lozano-Chiu M, Paetznick V, Nangia S, Rex JH (1999) Microdilution susceptibility testing of amphotericin B, itraconazole, and voriconazole against clinical isolates of Aspergillus and Fusarium species. J Clin Microbiol 37:3946-3951

9. Arsham AM, Howell JJ, Simon MC (2003) A novel hypoxiainducible factor-independent hypoxic response regulating mammalian target of rapamycin and its targets. J Biol Chem 278(32):29655-29660

10. Arthington-Skaggs BA, Motley M, Warnock DW, Morrison CJ (2000) Comparative evaluation of PASCO and national committee for clinical laboratory standards M27-A broth microdilution methods for antifungal drug susceptibility testing of yeasts. J Clin Microbiol 38(6):2254-2260

11. Baginski M, Resat H, Borowski E (2002) Comparative molecular dynamics simulations of amphotericin B-cholesterol/ergosterol membrane channels. Biochim Biophys Acta 1567(1-2):63-78

12. Baginski M, Tempczyk A, Borowski E (1989) Comparative conformational analysis of cholesterol and ergosterol by molecular mechanics. Eur Biophys J 17(3):159-166

13. Banaszynski LA, Liu CW, Wandless TJ (2005) Characterization of the FKBP. rapamycin. FRB ternary complex. J Am Chem Soc 127(13):4715-4721

14. Baldin V, Cans C, Knibiehler M, Doucommun B (1997) Phosphorylation of human CDC25B phosphatase by CDK1-cyclin A triggers its proteasome-dependent degradation. J Biol Chem 272(52):32731-32734

15. Baltz RH (2006) Marcel Faber roundtable: is our antibiotic pipeline unproductive because of starvation, constipation or lack of inspiration? J Ind Microbiol Biotechnol 33:507-513

16. Baltz RH (2008) Renaissance in antibacterial discovery from actinomycetes. Curr Opin Pharmacol 8:557-563

17. Barenholz Y (2012) Doxil ${ }^{\circledR}$-the first FDA-approved nano-drug: lessons learned. J Control Release 160(2):117-134

18. Benjamin D, Colombi M, Moroni C, Hall MN (2011) Rapamycin passes the torch: a new generation of mTOR inhibitors. Nat Rev Drug Discov 10:868-880

19. Bentley SD, Chater KF, Cerdeno-Tarrago AM et al (2002) Complete genome sequence of the model actinomycete Streptomyces coelicolor A3 (2). Nature 417(6885):141-147

20. Berdy J (2005) Bioactive microbial metabolites. J Antibiot 58(1):1-26

21. Beretta L, Gingras AC, Svitkin YV, Hall MN, Sonenberg N (1996) Rapamycin blocks the phosphorylation of 4E-BP1 and inhibits cap-dependent initiation of translation. EMBO J 15:658-664

22. Bernardi R, Liebermann DA, Hoffman B (2000) Cdc25A stability is controlled by the ubiquitin-proteasome pathway during cell cycle progression and terminal differentiation. Oncogene 19(20):2447-2454

23. Bierer BE, Mattila PS, Standaert RF, Herzenberg LA, Burakoff SJ, Crabtree G, Schreiber SL (1990) Two distinct signal transmission pathways in T lymphocytes are inhibited by complexes 
formed between an immunophilin and either FK506 or rapamycin. Proc Natl Acad Sci USA 87(23):9231-9235

24. Bjedov I, Toivonen JM, Kerr F, Slack C, Jacobson J, Foley A, Partridge L (2010) Mechanisms of life span extension by rapamycin in the fruit fly Drosophila melanogaster. Cell Metab 11(1):35-46

25. Blommaart EF, Luiken JJ, Blommaart PJ, van Woerkom GM, Meijer AJ (1995) Phosphorylation of ribosomal protein S6 is inhibitory for autophagy in isolated rat hepatocytes. J Biol Chem 270:2320-2326

26. Boatin B (2008) The onchocerciasis control programme in West Africa (OCP). Ann Trop Med Parasitol 102 Suppl 1:13-17

27. Bolster DR, Crozier SJ, Kimball SR, Jefferson LS (2002) AMP-activated protein kinase suppresses protein synthesis in rate skeletal muscle through down-regulated mammalian target of rapamycin (mTOR) signaling. J Biol Chem 277(27):23977-23980

28. Brajtburg J, Powderly WG, Kobayashi G, Medoff G (1990) Amphotericin B: current understanding of mechanisms of action. Antimicrob Agents Chemother 34(2):183-188

29. Brown EJ, Albers MW, Shin TB, Ichikawa K, Keith CT, Lane WS, Schreiber SL (1994) A mammalian protein targeted by G1-arresting rapamycin-receptor complex. Nature 369(6483):756-758

30. Brunn GJ, Hudson CC, Sekulic A, Williams JM, Hosoi H, Houghton PJ, Lawrence JC Jr, Abraham RT (1997) Phosphorylation of the translational repressor PHAS-I by the mammalian target of rapamycin. Science 277(5322):99-101

31. Burg RW, Miller BM, Baker EE et al (1979) Avermectins, new family of potent anthelmintic agents: producing organism and fermentation. Antimicrob Agents Chemother 15(3):361-367

32. Burnett PE, Barrow RK, Cohen NA, Snyder SH, Sabatini DM (1998) RAFT1 phosphorylation of the translational regulators p70 S6 kinase and 4E-BP1. Proc Natl Acad Sci USA 95(4):1432-1437

33. Calendi E, Di Marco A, Reggiani M, Scarpinato B, Valentini L (1965) On physico-chemical interactions between daunomycin and nucleic acids. Biochim Biophys Acta 103:25-49

34. Campbell WC (2012) History of avermectin and ivermectin, with notes on the history of other macrocyclic lactone antiparasitic agents. Curr Pharm Biotechnol 13(6):853-865

35. Capranico G, Kohn KW, Pommier Y (1990) Local sequence requirements for DNA cleavage by mammalian topoisomerase II in the presence of doxorubicin. Nucl Acids Res 18:6611-6619

36. Chiu E, Gold T, Fettig V, LeVasseur MT, Cressman DE (2015) Identification of a nuclear export sequence in the MHC CIITA. J Immunol 194(12):6102-6111

37. Choi J, Chen J, Schreiber SL, Clardy J (1996) Structure of the FKBP12-rapamycin complex interacting with the binding domain of human FRAP. Science 273(5272):239-242

38. Citro S, Miccolo C, Meloni L, Chiocca S (2015) PI3K/mTOR mediate mitogen-dependent HDAC1 phosphorylation in breast cancer: a novel regulation of estrogen receptor expression. $\mathrm{J}$ Mol Cell Biol 7(2):132-142

39. Cortes-Funes H, Coronado C (2007) Role of anthracyclines in the era of targeted therapy. Cardiovasc Toxicol 7(2):56-60

40. Craney A, Ahmed S, Nodwell J (2013) Towards a new science of secondary metabolism. J Antibiot (Tokyo) 66(7):387-400

41. Craney A, Ozimok C, Pimentel-Elardo SM, Capretta A, Nodwell JR (2012) Chemical perturbation of secondary metabolism demonstrates important links to primary metabolism. Chem Biol 19(8):1020-1027

42. Crespo JL, Hall MN (2002) Elucidating TOR signaling and rapamycin action: lessons from Saccharomyces cerevisiae. Microbiol Mol Biol Rev 66(4):579-591
43. Cully DF, Paress PS, Liu KK, Schaeffer JM, Arena JP (1996) Identification of a Drosophila melanogaster glutamate-gated chloride channel sensitive to the antiparasitic agent avermectin. J Biol Chem 271(33):20187-20191

44. Davey KG, Holmes AD, Johnson EM, Szekely A, Warnock DW (1998) Comparative evaluation of FUNGITEST and broth microdilution methods for antifungal drug susceptibility testing of Candida species and Cryptococcus neoformans. J Clin Microbiol 36:926-930

45. Davis SA, Vincent BM, Endo MM, Whitesell L, Marchillo K, Andes DR, Linquist S, Burke MD (2015) Nontoxic antimicrobials that evade drug resistance. Nat Chem Biol 11(7):481-487

46. de Kruijff B, Demel RA (1974) Polyene antibiotic-sterol interactions in membranes of Acholeplasma laidlawii cells and lecithin liposomes. III. Molecular structure of polyene antibioticcholesterol complexes. Biochim Biophys Acta 339:57-70

47. Deshais RJ (2014) Proteotoxic crisis, the ubiquitin-proteasome system, and cancer therapy. BMC Biol 12:94

48. Di Marco A, Gaetani M, Dorigotti L, Soldati M, Bellini O (1963) Studi sperimentali sull 'attivita' antineoplastica del nuovo antibiotic daunomicina. Tumori 49:203-217

49. Di Marco A, Silvestrini R, Di Marco S, Dasdia T (1965) Inhibiting effect of the new cytotoxic antibiotic daunomycin on nucleic acids and mitotic activity of HeLa cells. J Cell Biol 27(3):545-550

50. Dumont FJ, Melino MR, Staruch MJ, Koprak SL, Fischer PA, Sigal NH (1990) The immunosuppressive macrolides FK-506 and rapamycin act as reciprocal antagonists in murine $\mathrm{T}$ cells. $\mathrm{J}$ Immunol 144(4):1418-1424

51. Dumont FJ, Staruch MJ, Koprak SL, Melino MR, Sigal NH (1990) Distinct mechanisms of suppression of murine T cell activation by the related macrolides FK-506 and rapamycin. J Immunol 144(1):251-258

52. Dutcher JD (1968) The discovery and development of amphotericin B. Dis Chest 54(Suppl 1):296-298

53. Elofsson M, Splittgerber U, Myung J, Mohan R, Crews CM (1999) Towards subunit-specific proteasome inhibitors: synthesis and evaluation of peptide alpha', beta'-epoxyketones. Chem Biol 6(11):811-822

54. Enoch DA, Ludlam HA, Brown NM (2006) Invasive fungal infections: a review of epidemiology and management options. J Med Microbiol 55(7):809-818

55. Espinel-Ingroff A, Bartlett M, Bowden R, Chin NX, Cooper C Jr, Fothergrill A et al (1997) Muticenter evaluation of proposed standardized procedure for antifungal susceptibility testing of filamentous fungi. J Clin Microbiol 35:139-143

56. Espinel-Ingroff A, Dawson K, Pfaller M, Analissie E, Breslin B et al (1995) Comparative and collaborative evaluation of standardization of antifungal susceptibility testing for filamentous fungi. Antimicrob Agents Chemother 39:314-319

57. Fang Y, Vilella-Bach M, Bachmann R, Flanigan A, Chen J (2001) Phosphatidic acid-mediated mitogenic activation of mTOR signaling. Science 294(5548):1942-1945

58. Fenteany G, Standaert RF, Lane WS, Choi S, Corey EJ, Schreiber SL (1995) Inhibition of proteasome activities and subunit-specific amino-terminal threonine modification by lactacystin. Science 268(5211):726-731

59. Feling RH, Buchanan GO, Mincer TJ, Kauffman CA, Jensen PR, Fenical W (2003) Salinosporamide A: a highly cytotoxic proteasome inhibitor from a novel microbial source, a marine bacterium of the new genus Salinospora. Angew Chem Int Ed 42(3):355-357

60. Firtel RA, Meili R (2000) Dictyostelium: a model for regulated cell movement during morphogenesis. Curr Opin Genet Dev 10(4):421-427 
61. Floyd S, Favre C, Lasorsa FM et al (2007) The insulin-like growth factor-I-mTOR signaling pathway induces the mitochondrial pyrimidine nucleotide carrier to promote cell growth. Mol Biol Cell 18(9):3545-3555

62. Fornerod M, Ohno M, Yoshida M, Mattaj IW (1997) CRM1 is an export receptor for leucine-rich nuclear export signals. Cell 90(6):1051-1060

63. Frederick CA, Williams LD, Ughetto G, van der Marel GA, van Boom JH, Rich A, Wang AH (1990) Structural comparison of anticancer drug-DNA complexes: adriamycin and daunomycin. Biochemistry 29(10):2538-2549

64. Freedman DA, Levine AJ (1998) Nuclear export is required for degradation of endogenous p53 by MDM2 and human papillomavirus E6. Mol Cell Biol 18(12):7288-7293

65. Garcia-Martinez JM, Alessi DR (2008) mTOR complex 2 (mTORC2) controls hydrophobic motif phosphorulation and activation of serum- and glucocorticoid-induced protein kinase 1 (SKG1). Biochem J 416:375-385

66. Gerwitz DA (1999) A critical evaluation of the mechanisms of action proposed for the antitumor effects of the anthracycline antibiotics adriamycin and daunorubicin. Biochem Pharmacol 57(7):727-741

67. Ghannoum MA, Rice LB (1999) Antifungal agents: mode of action, mechanisms of resistance, and correlation of these mechanisms with bacterial resistance. Clin Microbiol Rev 12(4):501-517

68. Glickman MH, Ciechanove A (2002) The ubiquitin-proteasome proteolytic pathway: destruction for the sake of construction. Physiol Rev 82(2):373-428

69. Gomez-Escribano JP, Bibb MJ (2011) Engineering Streptomyces coelicolor for heterologous expression of secondary metabolite gene clusters. Microb Biotechnol 4(2):207-215

70. Gray KC et al (2012) Amphotericin primarily kills yeast by simply binding ergosterol. Proc Natl Acad Sci USA 109:2234-2239

71. Groll M, Kim KB, Kairies N, Huber R, Crews CM (2000) Crystal structure of epoxomicin: 20S proteasome reveals a molecular basis for selectivity of $\alpha^{\prime}, \beta^{\prime}$-epoxyketone proteasome inhibitors. J Am Chem Soc 122(6):1237-1238

72. Guertin DA, Stevens DM, Thoreen CC, Burds AA, Kalaany $\mathrm{NY}$ et al (2006) Ablation in mice of the mTORC components raptor, rictor, or $\mathrm{mLST} 8$ reveals that $\mathrm{mTORC} 2$ is required for signaling to Akt-FOXO and PKCalpha, but not S6K1. Dev Cell 11:859-871

73. Guo Y, Chekaluk Y, Zhang J, Du J, Gray NS, Wu CL, Kwiatkowski DJ (2013) TSC1 involvement in bladder cancer: diverse effects and therapeutic implications. J Pathol 230(1):17-27

74. Guzman ML, Swiderski CF, Howard DS, Grimes BA, Rossi RM, Szilvassy SJ, Jorand CT (2002) Preferential induction of apoptosis for primary human leukemic stem cells. Proc Natl Acad Sci USA 99(25):16220-16225

75. Hagting A, Karlsson C, Clute P, Jackman M, Pines J (1998) MPF localization is controlled by nuclear export. EMBO J 17(14):4127-4138

76. Hanada M, Sugawara K, Kaneta K, Toda S, Nishiyama Y, Tomita K, Yamamoto H, Konishi M, Oki T (1992) Epoxomicin, a new antitumor agent of microbial origin. J Antibiot Tokyo 45(11):1746-1752

77. Hamamoto T, Gunji S, Tsuji H, Beppu T (1983) Leptomycins A and $\mathrm{B}$, new antifungal antibiotics. I. Taxonomy of the producing strain and their fermentation purification and characterization. $\mathbf{J}$ Antibiot Tokyo 36(6):639-645

78. Hamamoto T, Seto H, Beppu T (1983) Leptomycins A and B, new antifungal antibiotics. II. Structure elucidation. J Antibiot Tokyo 36(6):646-650

79. Hamaoto T, Uozumi T, Beppu T (1985) Leptomycins A and $\mathrm{B}$, new antifungal antibiotics. III. Mode of action of leptomycin B on Schizosaccharomyces pombe. J Antibiot Tokyo 38(11):1573-1580

80. Hara K, Yonezawa K, Weng QP, Kozlowski MT, Belham C, Avruch J (1998) Amino acid sufficiency and mTOR regulate p70 S6 kinase and eIF-4EBP1 through a common effector mechanism. J Biol Chem 273:14484-14494

81. Harding MW, Galat A, Uehling DE, Schreiber SL (1989) A receptor for the immunosuppressant FK506 is a cis-trans peptidyl-prolyl isomerase. Nature 341:758-760

82. Harrison DE, Strong R, Sharp ZD et al (2009) Rapamycin fed late in life extends lifespan in genetically heterogeneous mice. Nature 460(7253):392-395

83. Heitman J, Movva NR, Hall MN (1991) Targets for cell cycle arrest by the immunosuppressant rapamycin in yeast. Science 253(5022):905-909

84. Hibbs RE, Gouaux E (2011) Principles of activation and permeation in an anion-selective Cys-loop receptor. Nature 474(7349):54-60

85. Hideshima T, Richardson P, Chauhan D, Palombella VJ, Elliott PJ, Adams J, Anderson KC (2001) The proteasome inhibitor PS-341 inhibits growth, induces apoptosis, and overcomes drug resistance in human multiple myeloma cells. Cancer Res 61(7):3071-3076

86. Houchens DP, Ovejera AA, Riblet SM, Slagel DE (1983) Human brain tumor xenografts in nude mice as a chemotherapy model. Eur J Cancer Clin Oncol 19(6):799-805

87. Hryciw DH, Pollock CA, Poronnik P (2005) PKC-alpha-mediated remodeling of the actin cytoskeleton is involved in constitutive albumin uptake by proximal tubule cells. Am J Physiol Renal Physiol 288(6):F1227-F1235

88. Huang W, Zhang Z, Han X, Tang J, Wang J, Dong S, Wang E (2002) Ion channel behaviour of amphotericin B in sterol-free and cholesterol- or ergosterol-containing supported phosphatidylcholine bilayer model membranes investigated by electrochemistry and spectroscopy. Biophys J 83(6):3245-3255

89. Hurley LH (2002) DNA and it associated processes as targets for cancer therapy. Nat Rev Cancer 2(3): 188-200

90. Ikeda H, Ishikawa J, Hanamoto A et al (2003) Complete genome sequence and comparative analysis of the industrial microorganism Streptomyces avermitilis. Nat Biotech 21:526-531

91. Inoki K, Li Y, Xu T, Guan KL (2003) Rheb GTPase is a direct target of TSC2 GAP activity and regulates mTOR signaling. Genes Dev 17:1829-1834

92. Inoki K, Li Y, Zhu T, Wu J, Guan KL (2002) TSC2 is phosphorylated and inhibited by Akt and suppresses mTOR signalling. Nat Cell Biol 4:646-657

93. Ito H, Miller SC, Billingham ME, Akimoto H, Torti SV, Wade R, Gahlmann R, Lyons G, Kedes L, Torti FM (1990) Doxorubicin selectively inhibits muscle gene expression in cardiac muscle cells in vivo and in vitro. Proc Natl Acad Sci USA 87:4275-4279

94. Jacinto E, Facchinetti V, Liu D, Soto N, Wei S, Jung SY, Huang Q, Qin J, Su B (2006) SIN1/MIP1 maintains rictor-mTOR complex integrity and regulates Akt phosphorulation and substrate specificity. Cell 127(1):125-137

95. Jacinto E, Loweith R, Schmidt A, Lin S, Ruegg MA, Hall A, Hall MN (2004) Mammalian TOR complex 2 controls the actin cytoskeleton and is rapamycin insensitive. Nat Cell Biol 6:1122-1128

96. Jagannath S, Vij R, Stewart AK et al (2012) An open-label single-arm pilot phase II study (PX-171-003-A0) of low-dose, single-agent carfilzomib in patients with relapsed and refractory multiple myeloma. Clin Lymphoma Myeloma Leuk 12(5):310-318 
97. Kumatori A, Tanaka K, Inamura N, Sone S, Ogura T, Matsumoto T, Tachikawa T, Shin S, Ichihara A (1990) Abnormally high expression of proteasomes in human leukemic cells. Proc Natl Acad Sci USA 87(18):7071-7075

98. Kaletta T, Hengartner MO (2006) Finding function in novel targets: C. elegans as a model organism. Nat Rev Drug Discov 5(5):387-398

99. Kane NS, Hirschberg B, Qian S et al (2000) Drug-resistant Drosophila indicate glutamate-gated chloride channels are targets for the antiparasitics nodulisporic acid and ivermectin. Proc Natl Acad Sci USA 97(25):13949-13954

100. Kim KB, Crews CM (2013) From epoxomicin to carfilzomib: chemistry, biology, and medical outcomes. Nat Prod Rep 30(5):600-604

101. Kim SY, Kim SJ, Kim BJ, Rah SY, Chung SN, Im MJ, Kim UH (2006) Doxorubicin-induced reactive oxygen species generation and intracellular $\mathrm{Ca} 2+$ increase are reciprocally modulated in rat cardiomyocytes. Exp Mol Med 38(5):535-545

102. Kimura N, Tokunaga C, Dalal S et al (2003) A possible linkage between AMP-activated protein kinase (AMPK) and mammalian target of rapamycin (mTOR) signalling pathway. Genes Cells 8(1):65-79

103. King AM, Reid-Yu SA, Wang W et al (2014) Aspergillomarasmine A overcomes metallo- $\beta$-lactamase antibiotic resistance. Nature 510(7506):503-506

104. Kissinger CR, Parge HE, Knighton DR et al (1995) Crystal structures of human calcineurin and the human FKBP12FK506-calcineurin complex. Nature 378(6557):641-644

105. Khamzina L, Veilleux A, Bergeron S, Maretta A (2005) Increased activation of the mammalian target of rapamycin pathway in liver and skeletal muscle of obese rats: possible involvement in obesity-linked insulin resistance. Endocrinology 146:1473-1481

106. Kohanski MA, Dwyer DJ, Collins JJ (2010) How antibiotics kill bacteria: from targets to networks. Nat Rev Microbiol 8(6):423-435

107. Koornneef M, Meinke D (2010) The development of Arabidopsis as a model plant. Plant J 61(6):909-921

108. Kotler-Brajtburg J, Medoff G, Kobayashi GS, Boggs S, Schlessinger D, Pandey RC, Rinehart KL Jr (1979) Classification of polyene antibiotics according to chemical structure and biological effects. Antimicrob Agents Chemother 15(5):716-722

109. Komatsu M, Komatsu K, Koiwai H et al (2013) Engineered Streptomyces avermitilis for heterologous expression of biosynthetic gene cluster for secondary metabolites. ACS Synth Biol 2(7):384-396

110. Komiyama K, Okada K, Hirokawa Y, Masuda K, Tomisaka S, Umezawa I (1985) J Antibiot Tokyo 38(2):224-229

111. Kudo N, Matsumori N, Taoka H et al (1999) Leptomycin B inactivates CRM1/exportin 1 by covalent modification at a cysteine residue in the central conserved region. Proc Natl Acad Sci USA 96(16):9112-9117

112. Le Bacquer O, Petroulakis E, Paglialunga S, Poulin F, Richard D, Cianflone K, Sonenberg N (2007) Elevated sensitivity to diet-induced obesity and insulin resistance in mice lacking 4E-BP1 and 4E-BP2. J Clin Invest 117:387-396

113. Li J, Grillo AS, Burke MD (2015) From synthesis to function via iterative assembly of $\mathrm{N}$-methyliminodiacetic acid boronate building blocks. Acc Chem Res 48(8):2297-2307

114. Li RK, Ciblak MA, Nordoff N, Pasarell L, Warnock DW, McGinnis MR (2000) In vitro activities of voriconazole, itraconazole, and amphotericin B against Blastomyces dermatidis, Coccidioides immitis, and Histoplasma capsulatum. Antimicrob Agents Chemother 44:1743-1746
115. Li X, Gianoulis TA, Yip KY, Gerstein M, Snyder M (2010) Extensive in vivo metabolite-protein interactions revealed by large-scale systematic analyses. Cell 143(4):639-650

116. Lin AC, Goldwasser E, Bernard EM, Chapman SW (1990) Amphotericin B blunts erythropoietin response to anemia. J Infect Dis 161(2):348-351

117. Ling LL, Schneider T, Peoples AJ et al (2015) A new antibiotic kills pathogens without detectable resistance. Nature 517(7535):455-459

118. Ling YH, Liebes L, Ng B, Buckley M, Elliott PJ, Adams J, Jiang JD, Muggia FM, Perez-Soler R (2002) PS-341, a novel proteasome inhibitor, induces Bcl-2 phosphorylation and cleavage in association with G2-M phase arrest and apoptosis. Mol Cancer Ther 1(10):841-849

119. Liu LF (1989) DNA topoisomerase poisons as antitumor drugs. Annu Rev Biochem 58:351-375

120. Loda M, Cukor B, Tam SW, Lavin P, Fiorentino M, Draetta GF, Jessup JM, Pagano M (1997) Increased proteasome-dependent degradation of the cyclin-dependent kinase inhibitor p27 in aggressive colorectal carcinomas. Nat Med 3(2):231-234

121. MacGregor RR, Bennett JE, Erslev AJ (1978) Erythropoietin concentration in amphotericin B-induced anemia. Antimicrob Agents Chemother 14(2):270-273

122. Maki CG, Huibregtse JM, Howley PM (1996) In vivo ubiquitination and proteasome-mediated degradation of p53. Cancer Res 56(11):2649-2654

123. Manfredi R, Fulgaro C, Sabbatani S, Legnani G, Fasulo G (2006) Emergence of amphotericin B-resistant Cryptococcus laurentii meningoencephalitis shortly after treatment for Cryptococcus neoformans meningitis in a patient with AIDS. AIDS Patient Care STDS 20(4):227-232

124. Martel RR, Klicius J, Galet S (1977) Inhibition of the immune response by rapamycin, a new antifungal antibiotic. Can J Physiol Pharmacol 55(1):48-51

125. Marty A, Finkelstein A (1975) Pores formed in lipid bilayer membranes by nystatin, differences in its one-sided and twosided action. J Gen Physiol 65(4):515-526

126. McCormack PL (2012) Carfilzomib: in relapsed, or relapsed and refractory, multiple myeloma. Drugs 72(15):2023-2032

127. McKenzie NL, Thaker M, Koteva K, Hughes DW, Wright GD, Nodwell JR (2010) Induction of antimicrobial activities in heterologous streptomycetes using alleles of the Streptomyces coelicolor gene absA1. J Antibiot Tokyo 53(4):177-192

128. Meng L, Mohan R, Kwok BHB, Eloffson M, Sin N, Crews CM (1999) Epoxomicin, a potent and selective proteasome inhibitor, exhibits in vivo anti-inflammatory activity. Proc Natl Acad Sci USA 96(18):10403-10408

129. Miller RA, Harrison DE, Astle CM et al (2010) Rapamycin, but not resveratrol or simvastatin, extends life span of genetically heterogeneous mice. J Gerontol A Biol Sci Med Sci 66(2):191-201

130. Moro S, Beretta GL, Dal Ben D, Nitiss J, Palumbo M, Capranico $G$ (2004) Interaction model for anthracycline activity against DNA topoisomerase II. Biochemistry 43(23):7503-7513

131. Mouri R, Konoki K, Matsumori N, Oishi T, Murata M (2008) Complex formation of amphotericin $\mathrm{B}$ in sterol-containing membranes as evidenced by surface plasmon resonance. Biochemistry 47:7807-7815

132. Mutka SC, Yang WQ, Dong SD, Ward SL, Craig DA, Timmermans PB, Murli S (2009) Identification of the nuclear export inhibitors with potent anticancer activity in vivo. Cancer Res 69(2):510-517

133. Naujokat C, Sezer O, Zinke H, Leclere A, Hauptmann S, Possinger K (2000) Proteasome inhibitors induced caspase-dependent apoptosis and accumulation of p21WAF1/Cip1 in human immature leukemic cells. Eur J Haematol 65:221-236 
134. Nett M, Ikeda H, Moore BS (2009) Genomic basis for natural product biosynthetic diversity in the actinomycetes. Nat Prod Rep 26(11):11362-11384

135. Nishi K, Yoshida M, Fujiwara D, Shishikawa M, Horinouchi S, Beppu T (1994) Leptomycin B targets a regulatory cascade of crm1, a fission yeast nuclear protein, involved in control of higher order chromosome structure and gene expression. J Biol Chem 269(9):6320-6324

136. Ochi K, Hosaka T (2012) New strategies for drug discovery: activation of silent or weakly expressed microbial gene clusters. Appl Microbiol Biotechnol 97(1):87-98

137. O'Connor OA, Stewart AK, Vallone M, Molineaux CJ, Kunkel LA, Gerecitano JF, Orlowski RZ (2009) A phase 1 dose escalation study of the safety and pharmacokinetics of the novel proteasome inhibitor carfilzomib (PR-171) in patients with hematologic malignancies. Clin Cancer Res 15(22):7085-7091

138. Ohnishi Y, Ishikawa J, Hara $\mathrm{H}$ et al (2008) Genome sequence of the streptomycin-producing microorganism Streptomyces griseus IFO 13350. J Bacteriol 190:4050-4060

139. Omura S, Crump A (2004) The life and times of ivermectin-a success story. Nat Rev Microbiol 2(12):984-989

140. Ouyang S, Hsuchou H, Kastin AJ, Pan W (2013) TNF stimulates nuclear export and secretion of IL-15 by acting on CRM1 and ARF6. PLoS One 8(8):e69356

141. Palacios DS et al (2011) Synthesis-enables functional group deletions reveal key underpinnings of amphotericin B ion channel and antifungal activities. Proc Natl Acad Sci USA 108:6733-6738

142. Palombella VJ, Rando OJ, Goldberg AL, Manitatis T (1994) The ubiquitinproteasome pathway is required for processing

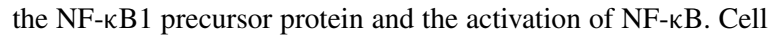
78(5):773-785

143. Pandey UB, Nichols CD (2011) Human disease models in Drosophila melanogaster and the role of the fly in therapeutic drug discovery. Pharmacol Rev 63(2):411-436

144. Patel S, Sprung AU, Keller BA, Heaton VJ, Fisher LM (1997) Identification of yeast DNA topoisomerase II mutants resistant to the antitumor drug doxorubicin: implications for the mechanisms of doxorubicin action and cytotoxicity. Mol Pharmacol 52(4):658-666

145. Pfaller MA, Arikan S, Lozano-Chu M et al (1998) Clinical evaluation of the ASTY colorimetric microdilution panel for antifungal susceptibility testing. J Clin Microbiol 36:2609-2612

146. Pfaller MA, Pappas PG, Wingard JR (2006) Invasive Fungal Pathogesn: current epidemiological trends. Clin Infect Dis 43(Suppl 1):S3-S14

147. Phung TL, Ziv K, Dabydeen D et al (2006) Pathological angiogenesis is induced by sustained Akt signaling and inhibited by rapamycin. Cancer Cell 10:159-170

148. Polak P, Cybulski N, Feige JN, Auwerx J, Ruegg MA, Hall MN (2008) Adipose-specific knockout of raptor results in lean mice with enhanced mitochondrial respiration. Cell Metab 8:399-410

149. Powers RW 3rd, Kaeberlein M, Caldwell SD, Kennedy BK, Fields S (2006) Extension of chronological life span in yeast by decreased TOR pathway signaling. Genes Dev 20(2):174-184

150. Readio JD, Bittman R (1982) Equilibrium binding of amphotericin B and its methyl ester and borate complex to sterols. Biochim Biophys Acta 685(2):219-224

151. Rigali S, Titegmeyer F, Barends S, Mulder S, Thomae AW, Hopwood DA, van Wezel GP (2008) Feast or famine: the global regulator DasR links nutrient stress to antibiotic production by Streptomyces. EMBO Rep 9(7):670-675

152. Robida-Stubbs S, Glover-cutter K, Lamming DW, Mizunuma M, Narasimhan SD, Neumann-Haefelin E, Sabatini DM, Blackwell TK (2012) TOR signaling and rapamycin influence longevity by regulating SKN-1/Nrf and DAF-16/FoxO. Cell Metab 15(5):713-724
153. Sabatini DM, Erdjument-Bromage H, Lui M, Tempst P, Snyder SH (1994) RAFT1: a mammalian protein that binds to FKBP12 in a rapamycin-dependent fashion and is homologous to yeast TORs. Cell 78(1):35-43

154. Sabers CJ, Martin MM, Brunn GJ, Williams JM, Dumont FJ, Wiederrecht G, Abraham RT (1995) Isolation of a protein target of the FKBP12-rapamycin complex in mammalian cells. J Biol Chem 270(2):815-822

155. Sachdev S, Hannink M (1998) Loss of IkappaB alpha-mediated control over nuclear import and DNA binding enables oncogenic activation of c-Rel. Mol Cell Biol 18(9):5445-5456

156. Salas V, Pastor FJ, Calvo E, Alvarez E, Sutton DA, Mayayo E, Fothergill AW, Rinaldi MG, Guarro J (2012) In vitro and in vivo activities of posaconazole and amphotericin B in a murine invasive infection by Mucor circinelloides: poor efficacy of posaconazole. Antimicrob Agents Chemother 56(5):2246-2250

157. Sarbassov DD, Ali SM, Kim DH et al (2004) Rictor, a novel binding partner of mTOR, defines a rapamycin-insensitive and raptor-independent pathway that regulates the cytoskeleton. Curr Biol 14:1296-1302

158. Sarbassov DD, Ali SM, Sengupta S, Sheen JH, Hsu PP, Bagley AF, Markhard AL, Sabatini DM (2006) Prolonged rapamycin treatment inhibits mTORC2 assembly and Akt/PKB. Mol Cell 22:159-168

159. Sarbassov DD, Guertin DA, Ali SM, Sabatini DM (2005) Phosphorylation and regulation of Akt/PKB by the rictor mTOR complex. Science 307(5712):1098-1101

160. Schinkel AH, Smit JJ, van Tellingen O, Beijnen JH, Wagenaar E, van Deemter L et al (1994) Disruption of the mouse mdr1a P-glycoprotein gene leads to a deficiency in the blood-brain barrier and to increased sensitivity to drugs. Cell 77(4):491-502

161. Schinkel AH, Wagenaar Mol CA, van Deemter L (1996) P-glycoprotein in the blood-brain barrier of mice influences the brain penetration and pharmacological activity of many drugs. J Clin Investig 97(11):2517

162. Shanmugam I, Cheng G, Terranova PF, Thrasher JB, Thomas CP, Li B (2007) Serum/glucocorticoid-induced protein kinase-1 facilitates androgen receptor-dependent cell survival. Cell Death Differ 14(12):2085-2094

163. Siegel DS, Martin T, Wang M et al (2012) A phase 2 study of single-agent carfilzomib (PX-171-003-A1) in patients with relapsed and refractory multiple myeloma. Blood 120(14):2817-2825

164. Siekierka JJ, Hung SHY, Pie M, Lin CS, Sigal NH (1989) A cytosolic binding protein for the immunosuppressant FK506 has peptidyl-prolyl isomerase activity but is distinct from cyclophilin. Nature 341:755-757

165. Spanogiannopoulos P, Thaker M, Koteva K, Waglechner N, Wright GD (2012) Characterization of a rifampin-inactivating glycosyltransferase from a screen of environmental actinomycetes. Antimicrob Agents Chemother 56(10):5061-5069

166. Sugar AM, Liu XP (1996) In vitro activity of voriconazole against selected fungi. Med Mycol 36:239-242

167. Sutton DA, Sanche SE, Revankar SG, Fothergill AW, Rinaldi MG (1999) In vitro amphotericin B resistance in clinical isolates of Aspergillus terrus, with a head-to-head comparison to voriconazole. J Clin Microbiol 37(7):2343-2345

168. Suzuki Y, Nakabayashi Y, Takahashi R (2001) Ubiquitin-protein ligase activity of $\mathrm{X}$-linked inhibitor of apoptosis protein promotes proteasomal degradation of caspase- 3 and enhances its anti-apoptotic effect in Fas-induced cell death. Proc Natl Acad Sci USA 98(15):8662-8667

169. Taagepera S, McDonald D, Loeb JE, Whitaker LL, McElroy AK, Wang JY, Hope TJ (1998) Nuclear-cytoplasmic shuttling of C-ABL tyrosine kinase. Proc Natl Acad Sci USA 95(13):7457-7462 
170. Tan C, Tasaka H, Yu KP, Murphy ML, Kamofsky DA (1967) Daunomycin, an antitumor antibiotic, in the treatment of neoplastic disease. Clinical evaluation with special reference to childhood leukemia. Cancer 20(3):333-353

171. Tee AR, Manning BD, Roux PP, Cantley LC, Blenis J (2003) Tuberous sclerosis complex gene products, tuberin and hamartin, control mTOR signaling by acting as a GTPase-activating protein complex toard Rheb. Curr Biol 13:1259-1268

172. Tewey KM, Rowe TC, Yang L, Halligan BD, Liu LF (1984) Adriamycin-induced DNA damage mediated by mammalian topoisomerase II. Science 226:466-468

173. Thaker MN, Waglechner N, Wright GD (2014) Antibiotic resistance-mediated isolation of scaffold-specific natural producers. Nat Protoc 9(6):1469-1479

174. Tremblay F, Brule S, Hee Um S, Li Y, Masuda K, Roden M, Sun XJ, Krebs M, Polakiewicz RD, Tomas G, Maretta A (2007) Identification of IRS-1 Ser-1101 as a target of S6K1 in nutrientand obesity-induced insulin resistance. Proc Natl Acad Sci USA 104:14056-14061

175. Um SH, Frigerio F, Watanabe M, Picard F, Joaquin $M$ et al (2004) Absence of S6 K protects against age- and diet-induced obesity while enhancing insulin sensitivity. Nature 431:200-205

176. van Hoogevest P, de Kruijff B (1978) Effect of amphotericin B on cholesterol-containing liposomes of egg phosphatidylcholine and didocosenoyl phosphatidylcholine. A refinement of the model for the formation of pores by amphotericin B in membranes. Biochim Biophys Acta 511(3):397-407

177. Vertut-Croquin A, Bolard J, Chabbert M, Gary-Bobo C (1983) Differences in the interaction of the polyene antibiotic amphotericin B with the cholesterol- or ergosterol-containing phospholipid vesicles. A circular dichroism and permeability study. Biochemistry 22(12):2939-2944

178. Vézina C, Kudelski A, Sehgal SN (1975) Rapamycin (AY22,989 ), a new antifungal antibiotic. I. Taxonomy of the producing streptomycete and isolation of the active principle. $\mathrm{J}$ Antibiot 28:721-726

179. Vincent BM, Lancaster AK, Scherz-Shouval R, Whitesell L, Lindquist S (2013) Fitness trade-offs restict the evolution of resistance to amphotericin B. PLoS Biol 11(10):e1001692

180. Vij R, Wang M, Kaufman JL et al (2012) An open-label, singlearm, phase 2 (PX-171-004) study of single-agent carfilzomib in bortezomib-naive patients with relapsed and/or refractory multiple myeloma. Blood 199(24):5661-5670

181. Wada A, Fukuda M, Mishima M, Nishida E (1998) Nuclear export of actin: a novel mechanism regulating the subcellular localization of a major cytoskeletal protein. EMBO J 17(6):1635-1641

182. Wang S, Lloyd RV, Hutzler MJ, Rosenwald IB, Safran MS, Patwardhan NA, Khan A (2001) Expression of eukaryotic translation initiation factors $4 \mathrm{E}$ and $2 \alpha$ correlates with the progression of thyroid carcinoma. Thyroid 11(12):110-117
183. Wei D, Lei B, Tang M, Zhan CG (2012) Fundamental reaction pathway and free energy profile for inhibition of proteasome by epoxomicin. J Am Chem Soc 134(25):10436-10450

184. Welscher YM, Jones L, van Leeuwen MR, Dijksterhuis J, de Kruijff B, Eitzen G, Breukink E (2010) Natamycin inhibits vacuole fusion at the priming phase via a specific interaction with ergosterol. Antimicrob Agents Chemother 54(6):2618-2625

185. White TC, Marr KA, Bowden RA (1998) Clinical, cellular, and molecular factors that contribute to antifungal drug resistance. Clin Microbiol Rev 11(2):382-402

186. Wingard JR, Kubilis P, Lee L, Yee G, White M, Walshe L, Bowden R, Anaissie E, Hiemenz J, Lister J (1999) Clinical significance of nephrotoxicity in patients treated with amphotericin B for suspected or proven aspergillosis. Clin Infect Dis 29(6):1402-1407

187. Wolff B, Sanglier JJ, Wang Y (1997) Leptomycin B is an inhibitor of nuclear export: inhibition of nucleo-cytoplasmic translocation of the human immunodeficiency virus type 1 (HIV-1) Rev protein and Rev-dependent mRNA. Chem Biol 4(2):139-147

188. Wolstenholme AJ (2012) Glutamate-gated chloride channels. J Biol Chem 287:40232-40238

189. Wong AS, Kim SO, Leung PC, Auersperg N, Pelech SL (2004) Profiling of protein kianses in the neoplastic transformation of human ovarian surface epithelium. Gynecol Oncol 82(2):305-311

190. Yang YL, Ho YA, Cheng HH, Ho M, Lo HJ (2004) Susceptibilities of Candida species to amphotericin B and fluconazole: the emergence of fluconazole resistance in Candida tropicalis. Infect Control Hosp Epidemiol 25(1):60-64

191. Yang J, Bardes ES, Moore JD, Brennan J, Powers MA, Kornbluth S (1998) Control of cyclin B1 localization through regulated binding of the nuclear export factor CRM1. Genes Dev 12(14):2131-2143

192. Yashiroda Y, Yoshida M (2003) Nucleo-cytoplasmic transport of proteins as a target of therapeutic drugs. Curr Med Chem 10:741-748

193. Yeo EJ, Ryu JH, Cho YS, Chun YS, Huang LE, Kim MS, Park JW (2006) Amphotericin B blunts erythropoietin response to hypoxia by reinforcing FIH-mediated repression of HIF1. Blood 107(3):916-923

194. Yoon V, Nodwell JR (2014) Activating secondary metabolism with stress and chemicals. J Ind Microbiol Biotechnol 41(2):415-424

195. Zeman SM, Phillips DR, Crothers DM (1998) Characterization of covalent adriamycin-DNA adducts. Proc Natl Acad Sci USA 95(20):11561-11565

196. Zinzalla V, Stracka D, Oppliger W, Hall MN (2011) Activation of mTORC2 by association with the ribosome. Cell 144(5):757-768 